\section{To: (Receiving Organization) \\ DISTRIBUTION \\ 5. Proj./Prog./Dept./Div.: \\ INTERIM STABILIZATION}

\section{Originator Remarks:}

ATTACHED IS AN ACCEPTANCE FOR BENEFICIAL USE (ABU) FOR THE READINESS OF PUMPING AND INSTRUMENTATION CONTROL SKID "L".

11. Receiver Remarks:

NONE

3. From: (Originating Organization)
INTERIM STABILIZATION
6. Design Authority/Design Agent/Cog. Engr.:
W. F. ZUROFF

W. F. ZUROFF

\section{Related EDT No.: \\ $\mathrm{N} / \mathrm{A}$ \\ 7. Purchase Order No:: \\ $\mathrm{N} / \mathrm{A}$ \\ 9. Equip./Component No.}

$\mathrm{N} / \mathrm{A}$

10. System/Bidg./Facility:

241-G

12. Major Assm. Dwg. No.

$\mathrm{N} / \mathrm{A}$

13. Permit/Permit Application No.:

$\mathrm{N} / \mathrm{A}$

14. Required Response Date:

$\mathrm{N} / \mathrm{A}$

\begin{tabular}{|c|c|c|c|c|c|c|c|c|}
\hline 15. & & DATA TR & ANSMITTE & & (F) & (G) & (H) & (l) \\
\hline $\begin{array}{l}\text { (A) } \\
\text { Item } \\
\text { No. }\end{array}$ & (B) Document/Drawing No. & $\begin{array}{l}\text { (C) Sheet } \\
\text { No. }\end{array}$ & (D) Rev. & (E) Title or Description of Data Transmitted & $\begin{array}{l}\text { Approval } \\
\text { Desig- } \\
\text { nator }\end{array}$ & $\begin{array}{c}\text { Reason } \\
\text { for Trans- } \\
\text { mittal }\end{array}$ & $\begin{array}{c}\text { Origi- } \\
\text { nator } \\
\text { Dispo- } \\
\text { stion }\end{array}$ & $\begin{array}{c}\text { Receiv- } \\
\text { er } \\
\text { Dispo- } \\
\text { sition } \\
\end{array}$ \\
\hline 1 & $\mathrm{RPP}-5235$ & $\mathrm{~N} / \mathrm{A}$ & 0 & ACCEPTANCE FOR BENEEICIAL & SQ & 1 & 1 & 1 \\
\hline & & & & USE， PUMPING & & & & \\
\hline & & & & INSTRUMENTATION AND & & & & \\
\hline & & & & CONTROL SKID "L" & & & & \\
\hline & & & & & & & & \\
\hline & & & & & & & & \\
\hline & & & & & & & & \\
\hline
\end{tabular}

16.

KEY
Approval Designator $(F)$

$E, S, Q, D$ OR N/A (See WHC-CM-3-5 Sec. 12.7)

1. Approval
2. Release
3. Information

Reason for Transmittal (G)

4. Review

5. Dist. (Receipt Acknow. Required)
Disposition $(H) \&(I)$

\begin{tabular}{|ll}
\multicolumn{2}{|c}{ Disposition (H) \& (I) } \\
$\begin{array}{ll}\text { 1. Approved } & \text { 4. Reviewed no/comment } \\
\text { 2. Approved w/comment } & \text { 5. Reviewed w/comment } \\
\text { 3. Disapproved w/comment } & \text { 6. Receipt acknowledged }\end{array}$ \\
\hline
\end{tabular}

SIGNATURE/DISTRIBUTION

(See Approval Designator for required signatures)

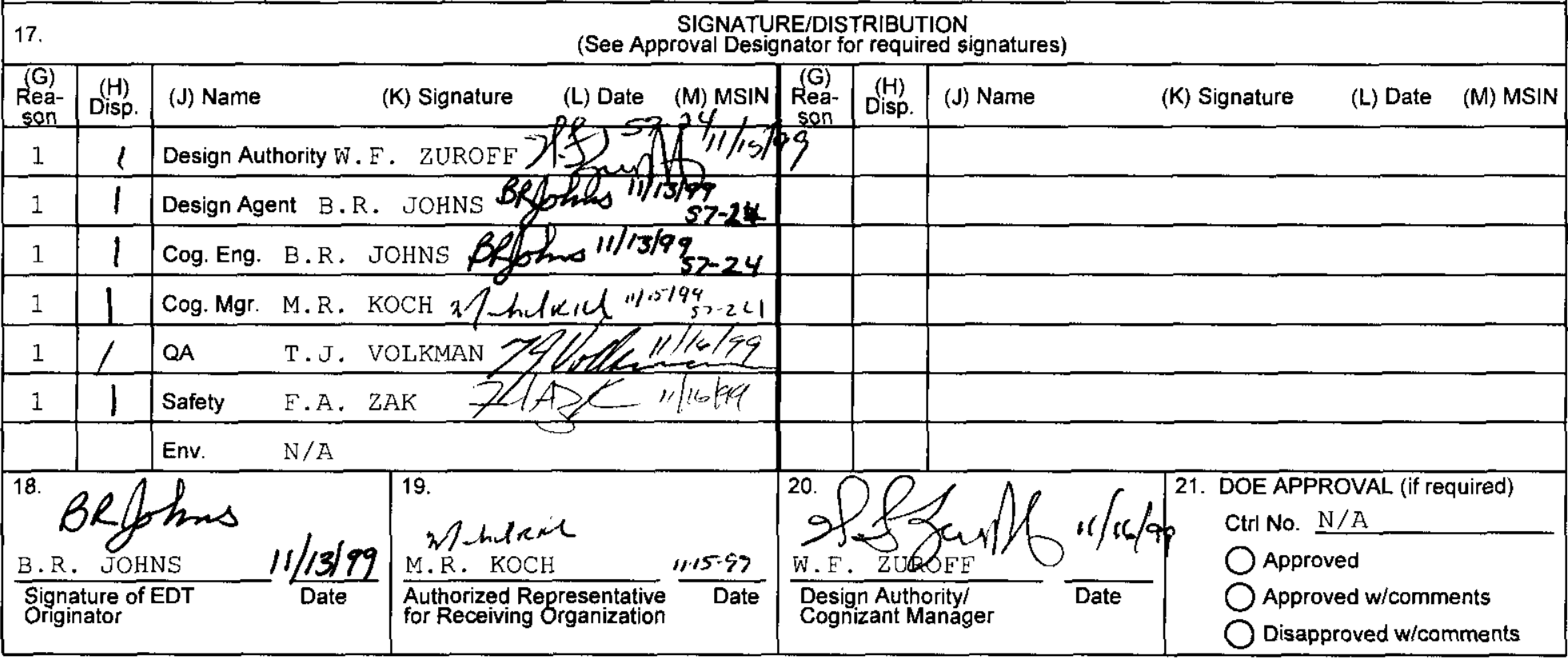




\title{
ACCEPTANCE FOR BENEFICIAL USE PUMPING INSTRUMENTATION AND CONTROL SKID "L"
}

M. R. KOCH

LOCKHEED MARTIN HANFORD CORPORATION

Richland, WA 99352

U.S. Department of Energy Contract DE-AC06-96RL13200

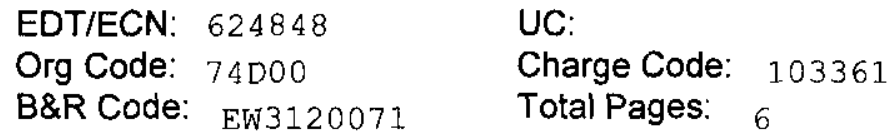

Key Words: PICS, SALT WELL, SKID, INTERIM STABILIZATION, ABU

\begin{abstract}
:
This document is a Final Acceptance for Beneficial Use (ABU) for the readiness of Pumping Instrumentation and Control (PIC) skid "L". All the testing and documentation for PIC skid "L" is completed and the skid is ready for use in the field for pumping of tank U-105.
\end{abstract}

TRADEMARK DISCLAIMER. Reference herein to any specific commercial product, process, or service by trade name, trademark, manufacturer, or otherwise, does not necessarily constitute or imply its endorsement, recommendation, or favoring by the United States Government or any agency thereof or its contractors or subcontractors.

Printed in the United States of America. To obtain copies of this document, contact: Document Control Services, P.O. Box 950, Mailstop H6-08, Richland WA 99352, Phone (509) 372-2420; Fax (509) 376-4989.

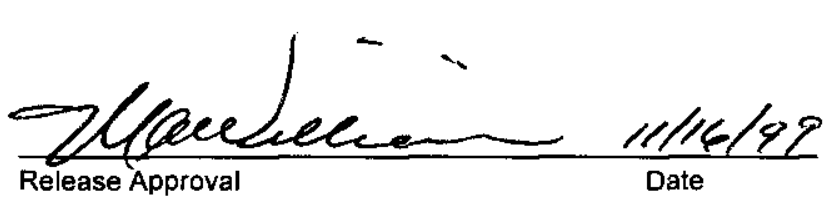

Approved For Public Release 
RPP-5235

REVISION 0

\section{ACCEPTANCE FOR BENEFICIAL USE PUMPING AND INSTRUMENTATION CONTROL SKID "L"}

\subsection{INTRODUCTION}

This is a final Acceptance for Beneficial Use (ABU) for Pumping and Instrumentation Control (PIC) skid "L". PIC skid "L" is ready for pumping tank U-105. All the testing and documentation has been completed as required on the ABU checklist. This ABU covers only the readiness of the PIC skid "L". Other U-farm preparations including dilution tank fabrication, portable exhauster readiness, leak detection, valve pit preparation, and the Operation Control Station readiness are not part of this ABU.

PIC skid " $L$ " is a new skid fabricated and tested at Site Fabrication Services. The skid controls the jet pump and monitors various instruments associated with the pumping operation. This monitoring includes leak detection along the waste transfer route and flammable gases in the pump pit.

\subsection{DESCRIPTION OF WORK COMPLETED}

\subsection{ENGINEERING TASK PLAN}

Engineering Task Plan (ETP) HNF-3828, revision 0 was written and issued to outline the work required for completion of the PIC skid projects. This document includes an estimated schedule for the completion of eleven PIC skids.

\subsection{DESIGN CRITERIA}

Functional design criteria document HNF-4481, revision 0 was prepared and issued. This document outlines the basic functional requirements for the PIC skid. The design is based upon PIC skids already in use in the field.

\subsection{ACCEPTANCE TESTING}

An acceptance test was performed upon completion of the fabrication of skid "L". The Acceptance Test Procedure (ATP) was provided in document RPP-5055, revision 0. The results of the testing are documented in RPP-5056, revision 0.

\subsection{OPERATIONAL TESTING}

Operational Test Procedure OTP-200-004, revision A-18 shall be completed for the testing of PIC skid "L". Most of the operational testing was completed in the shop under the ATP procedure, with the remaining testing completed upon set up at U-105 
RPP-5235

REVISION 0

\subsection{DESIGN DRAWINGS}

Skid drawings have been released under ECN 651953. ECN 648489 modified skid "L" due to PS-1 pressure switch changing to a pressure transducer and a second control output being added to the PLC for the dilution system. ECN 648497 corrected some drafting errors on the drawings for field wiring. The drawings represent the final as-built condition of PIC skid " $L$ ". There are no outstanding ECN's against these drawings.

\subsection{INSPECTIONS}

A pressure vessel inspection was performed on the air compressor and pressurized water tanks. This inspection verified proper ASME rated tanks and proper relief valves installation.

A National Electrical Code (NEC) inspection was performed on the electrical power equipment and wiring on the skid. A blue inspection sticker was placed on the inside of the door of the distribution panel indicating a satisfactory inspection.

\subsection{SOFTWARE CONFIGURATION}

Programs were written and installed on the PIC skid for the Programmable Logic Controller (PLC) and the Data Table Access Module (DTAM). These programs were based upon the existing programs installed in the PIC skid "K". For skid "L", these programs are documented in RPP-5236, revision 0, PLC/DTAM SOFTWARE PROGRAMS FOR PUMPING AND INSTRUMENTATION CONTROL SKID " $L$ ".

\subsection{TRAINING}

PIC skid "L" is similar to PIC skid " $\mathrm{K}$ ". Information for PIC skid " $\mathrm{K}$ " has been forwarded to the training department for incorporation into the continuing training program. No special training sessions will be required for the operators prior to startup of PIC skid "L" at U-105 since it is very similar to PIC skid "K". No special training is required for maintenance. The same type instruments and controls are used on the new skid as on skid "K". 
RPP-5235

REVISION 0

\subsection{OPERATING AND MAINTENANCE PROCEDURES}

Operating and maintenance procedures have been updated for the deployment of PIC skid " $L "$ in the field. The following is a list of procedures and data sheets that were updated for the operation and maintenance of the new PIC skid "L".

\subsubsection{Operating Procedures}

TO-505-105, (Pump operation including startup and shutdown)

TO-430-102, (Material Balance calculating)

ARP-T-501-001, (Alarm response guide)

\subsubsection{Calibration Procedures}

6-TF-509, Pressure and Vacuum Gauges Calibration

6-CVT-520, Foxboro E69F Series Current to Pneumatic Signal Converter

6-PCD-508, Calibrate Pressure Switches

6-PCD-361, Foxboro Intelligent Pressure Transmitter

6-PCD-524, Omega Model PX880/PX881 Electronic Pressure Transmitter Calibration

6-FCD-454, Yokogawa Model AE14 Magnetic Flow Converter Calibration

TF-FT-309-001, Perform Saltwell Flush Water High Pressure Detection

\subsubsection{Data Sheets}

WT-06421, SALW-PS-6004L: Air compressor control switch WT-06419, SALW-LT-6003L: Water tank level transmitter WT-06422, SALW-SGT-6001L: Specific gravity transmitter WT-06405, SALW-FQIT-6001L: Magnetic flow converter WT-06423, SALW-WFT-6002L: Weight factor transmitter WT-06418, SALW-CONV-6001L: Current to pneumatic converter WT-06406, SALW-PI-6001L: Water pressure on drip system WT-06407, SALW-PI-6002L: Air pressure at low side weight factor dip tube WT-06408, SALW-PI-6003L: Air pressure at low side specific gravity dip tube WT-06409, SALW-PI-6004L: Air pressure at high side dip tube WT-06411, SALW-PI-6006L: Air compressor pressure indicator WT-06412, SALW-PI-6007L: After filter air pressure indicator WT-06414, SALW-PI-6008L: Air pressure on water tank WT-06410, SALW-PI-6005L: Air pressure to DOV WT-06415, SALW-PI-6011L: Discharge pressure indicator WT-06416, SALW-PI-6012L: Suction pressure indicator WT-06403, SALW-PT-6014L: Jumper flush pressure transducer WT-06401, SALW-PT-6013L: Recirculation flush pressure transducer WT-06402, SALW-PT-6013L: Recirculation flush pressure transducer WT-06404, SALW-PT-6014L: Jumper flush pressure transducer WT-06405, SALW-FQIT-6001L: Magnetic flow converter 
RPP-5235

REVISION 0

\subsection{SPARE PARTS}

The spare parts list has been updated to include parts for the new skid. This is documented in support document RPP-4853, revision 0. Spare parts stocking has not been completed.

\subsection{VENDOR INFORMATION}

Vendor information for the components on the new skid has been assembled and will be added to the existing Certified Vendor Information (CVI) file. The vendor file to be updated is VI 22726. 
RPP-5235

REVISION 0

\begin{tabular}{|c|c|c|c|c|c|}
\hline \multicolumn{6}{|c|}{ ACCEPTANCE FOR BENEFICIAL USE } \\
\hline & ENGINEERING & RESPONSIBLE & & ADP & RESPONSIBLE \\
\hline $\mathrm{X}$ & Engineering Task Plan & Engineering & $\mathrm{X}$ & Software Configuration Mgmt & Engineering \\
\hline \multirow[t]{7}{*}{$\mathrm{X}$} & Activity Schedule & Engineering & & System Requirement Spec. & \\
\hline & FSAR Report & & & Software Design Description & \\
\hline & Interim Safety Basis update & & & Software Validation/Verification & \\
\hline & Safety Assessment & & & & \\
\hline & Safety Equipment List & & & TRAINING & \\
\hline & Operational Safety Req. & & & Training Plan & \\
\hline & Operational Safety Doc. & & & Training Manuals & \\
\hline \multirow[t]{3}{*}{$\mathrm{X}$} & Design Criteria & Engineering & $\mathrm{X}$ & Training to Operating Crew (3) & Operations/Trng. \\
\hline & System Design Description & & $X$ & Training to Maintenance Crew (3) & Maint/Trng. \\
\hline & Test Plan/Specifications & & & Training Mock-Up & \\
\hline $\mathrm{X}$ & $\begin{array}{l}\text { Acceptance Test Procedure and } \\
\text { Final Test Report }\end{array}$ & Engineering & & & \\
\hline $\mathrm{X}$ & Operational Test Procedure (1) & Engineering & & & \\
\hline \multirow[t]{10}{*}{$\mathrm{X}$} & Final Test Report (2) & Engineering & & OPERATIONS/MAINT & \\
\hline & $\begin{array}{l}\text { Environmental lmpact } \\
\text { Statement }\end{array}$ & & & $\begin{array}{l}\text { Operating and Maintenance } \\
\text { Manuals }\end{array}$ & \\
\hline & Environmental Report & & $\mathrm{X}$ & Operating Procedures & *Eng/Proc.Wtr. \\
\hline & Environmental Permit & & $\mathrm{X}$ & Surveillance Procedures & *Eng/Proc. Wtr. \\
\hline & $\begin{array}{l}\text { Hazardous Waste Disposal } \\
\text { Plan/Procedures }\end{array}$ & & $\mathrm{X}$ & Calibration Procedures & *Eng/Proc. Wtr. \\
\hline & $\begin{array}{l}\text { Solid Waste Disposal Plan or } \\
\text { Procedures }\end{array}$ & & $\mathrm{X}$ & $\begin{array}{l}\text { Preventative Maintenance } \\
\text { Procedures }\end{array}$ & *Eng/Proc. Wtr. \\
\hline & Stress/Seismic Analysis & & & Repair/Maintenance Procedure & \\
\hline & Stress/Design Report & & & Functional Check Procedures & \\
\hline & Design Specifications/Report & & $\mathrm{X}$ & PM/S Datasheets & *Eng/Proc. Wtr. \\
\hline & Equipment Specifications & & $\mathrm{X}$ & $\begin{array}{l}\text { Final Joint Safety walkdown by } \\
\text { Operations, Engineering, } \\
\text { maintenance, and Health Physics }\end{array}$ & Engineering \\
\hline \multirow[t]{3}{*}{$\mathrm{X}$} & Procurement Specifications & Engineering\# & & & \\
\hline & Construction Specifications & & & QUALITY ASSURANCE & \\
\hline & Essential Material Specs. & & $\bar{X}$ & Inspection Plan & *QC/Eng. \\
\hline \multirow[t]{3}{*}{$\mathrm{X}$} & Final Design Drawings & Eng/Drafting & & QAPP & \\
\hline & Installation Drawings & & & QAPjP & \\
\hline & Installation Work Plan & & & & \\
\hline \multirow[t]{5}{*}{$\mathrm{X}$} & As-built Drawings & *Eng/Drafting & & PROCUREMENT & \\
\hline & Interface Control Drawings & & $\mathrm{X}$ & Vendor Information Files (2) & Engineering \\
\hline & IEFD Drawings & & & Comprehensive Equip. List & \\
\hline & System Drawings & & $\mathrm{X}$ & Spare Parts List & Engineering \\
\hline & Drawing Tree & & $\mathrm{X}$ & Spare Parts in Stock (2) & Engineering \\
\hline $\mathrm{X}$ & $\begin{array}{l}\text { Incorporate Outstanding } \\
\text { Project Generated ECNs }\end{array}$ & *Eng/Drafting & $\mathrm{X}$ & NEC Inspection & NEC Inspector \\
\hline $\mathrm{X}$ & Third Party Inspection & Third Party Insp & & & \\
\hline
\end{tabular}

*Lead Organization \#Required only if PIC skids procured off-site

(1) The Operation Test shall be satisfactorily completed prior to startup of U-105.

(2) These items do not require completion prior to start up of U-105. See sections 2.4, 2.10 and 2.11 for additional information.

(3) See section 2.8 for additional information. 